\title{
Freedom and Gender Equality in EU Family Policy Tools
}

\section{Lucie Novotna*}

*Department of Social Policy and Social Work, Faculty of Social Studies, Masaryk University, Brno, Czech Republic.

E-mail: novotna@fss.muni.cz

The aim of this article is to look critically at the implications of gender equality concepts for individual freedom as conceptualised by the philosopher Isaiah Berlin. The scientific literature addressing the problem of freedom and gender equality with regard to public policy is considerably fragmented. Based on contextual literature, this article will offer four concepts of freedom that serve as analytical categories. I will analyse work/family reconciliation policy tools as introduced at the level of the European Union and reconnect them to three traditions of gender equality. The article reflects on historically embedded dichotomy between positive and negative freedom visible in gendered distinction between public and private. The main findings show that the relationship between freedom and equality is mediated by the selected policy tools suggesting that some policy tools expand freedom of all individuals while others indicate a possible limit for freedom.

Keywords: Gender equality, freedom, social policy, work-family reconciliation, family policy.

\section{Introduction}

In recent decades, prominent feminist scholars have comprehensively discussed the relationship between social policy and gender equality. These accounts have brought attention to the gendered normative assumptions embedded in policy theory and practice: the gendered division of labour that underlies the welfare state (about the conjunction of work and care and connected family policy models, see Orloff, 1996), the feminist critique of theories of citizenships (O'Connor, 1993; Knijn and Kremer, 1997), the critique of the typologies of welfare state (see Lewis, 1997), etc. Because women's life experiences were theoretically invisible or neglected in social policy theorising, the design of welfare states reproduced women's economic dependence and placed women's primary responsibility in the domestic sphere. The attention of feminists thus brought the gender dimension to the idea of social rights, making the case that, for women, the possibility of making autonomous choices is primarily rooted in contextual social relations of work and family. Social policies thus should serve to rectify gender inequalities by addressing men's and women's ties to unpaid labour, care and to employment.

This feminist argument relies on three premises. First, it presupposes a specific concept of freedom. Second, it places the crux of the issue on the gendered distinction 
between the public and private spheres. Third, social policy is connected to a normative notion of gender equality that can have multiple meanings.

First, the possibility of exercising freedom is dependent on the embedded gender order. Gendered practices are derived from an organisation of the social structure, as more equal societies grant women 'choice' (Lewis, 2006a) or the possibility of self-government (Pateman, 2004). This gives legitimacy to the state intervention, as it increases positive freedom, linking gender equality to a broader conception of social liberalism. There is, however, an alternative notion of freedom connected to classical liberalism. Negative freedom is understood as the space of a person or a group of people in which no other entity can interfere. The role of a state is to guarantee such space and minimise its interventions. The aim of this article is to examine the complex interrelations between freedom, gender equality and social policy when accounting for both notions of liberty.

In existing scholarship, the issue has been considered from a historical perspective (by tracking the changing relationships between liberalism and gender equality, e.g. O'Connor et al., 1999) or a critical perspective (by reflecting on the role of a woman as an individual during classic liberal historical periods, e.g. Pateman, 1988). This article decontextualises both notions of freedom from their historical groundings and offers a conceptual perspective. The article will thus develop an analytical framework based on concepts of freedom to examine selected family policy tools that are connected to gender equality.

Second, the discussion on freedom and feminism is linked to the conceptual dichotomy between the public and private/domestic spheres in asking the question of how much state intervention in family functioning is justifiable. Feminism aims to recognise the importance of unpaid work and care while simultaneously encouraging women to enter the public sphere (Ray et al., 2010: 197). Even within this argument, however, the encouragement for men to engage in unpaid labour by social policy tools is implemented mainly in countries of social democratic regimes (Pfau-Effinger, 2005: 323324). This indicates sensitivity to state intervention in the private sphere, and the complex nature of freedom in gender equality.

The problematic relations between the public and private perspectives concerning freedom are translated in this article into two conceptual and methodical choices. First, this article will ground the concept in a singular perspective that pays adequate attention to both notions of freedom. The dichotomy has existed in Western political thought since the eighteenth century (Cherniss, 2013: 146), but the most influential theoretical elaboration of both notions was presented in the essay Two Concepts of Liberty by the philosopher Berlin (2005). As Berlin's essay is not grounded in a social policy discussion, it does not reflect on the role of women, and it does not take a contemporary critical outlook on the public/private dichotomy. This is its greatest strength, as it stays focused exclusively on the notion of freedom and elaborates on interconnections between the subject's freedom and society. Simultaneously, this focus is its greatest weakness, as the essay does not reflect on the complexity of relations between social context and an individual developed in gender equality discussion.

Third, to introduce the contemporary public/private dichotomy problem, this article will analyse social policy tools that aim to address asymmetric gendered behaviour concerning the organisation of paid and unpaid labour. During the past decades, the erosion of traditional two-parent male-breadwinner families associated with the emergence of new social risks has led to an increase in tension between work and family 
(Lewis, 2006a). The burden was primarily on women who entered the labour market and were still expected to do unpaid domestic work (Lewis, 2006b). The changes were echoed in the social policy literature by systematising welfare state family models (see Sainsbury, 1996 or Korpi, 2000) or incentivising the creation of new dimensions for comparing the capacity of the welfare state to address such issues. For example, according to women's capacity to form and maintain independent households (Orloff, 1992) or according to the extent welfare states reinforce the male breadwinner model (Sainsbury, 1999). Policy practices also reflected these challenges and brought the harmonisation of work and care to the fore (Lewis, 2006a). This article will thus examine the un/paid work reconciliation tools introduced between 1982-2000 at the EU level (Stratigaki, 2004).

The tools presented adhere to different policy strategies and policy goals, which are derived from different notions of gender equality. Gender equality was conceptualised in the sameness/difference debate on citizenship status. The concept of 'sameness' (vis-à-vis men) stressed women's inclusion in the public sphere, and the concept of 'difference' called for recognising women's care work (Gornick and Meyers, 2002). In the social policy debate, this schism was translated into three conceptions of gender equality: as 'sameness' or 'inclusion', linked to promoting equal opportunities; 'difference' or 'reversal', which affirms difference from male norms (linked to, e.g. positive action); and 'transformation' or 'displacement', which aims to transform gender norms (e.g. by gender mainstreaming, see Verloo and Lombardo, 2007). I will use the latter definitions provided by Squires (1999) as a heuristic to systematise the tools relating to paid and unpaid work.

The article is structured as follows. First, I will introduce the concepts of negative and positive freedom and develop a theoretical framework by linking it conceptually to the notion of gender equality. Second, the analysis section will introduce the three conceptualisations of gender equality and the family policies associated with them. Later, the policies will be linked to gender equality concepts, and their implications for both notions of freedom will be discussed.

\section{Theoretical framework}

\section{Negative freedom}

Negative freedom is the absence of barriers, limitations, and outside interference from other people or institutions. In other words, it is the absence of obstacles that are outside the subject and that prevent her/him from acting ('freedom from', Berlin, 2005).

Berlin explains this concept based on the question 'What is the area within which the subject - a person or group of persons - is or should be left to do or be what he is able to do or be, without interference by other persons?' (Berlin, 2005: 233). The answer to this question is the space within which an individual can choose among many alternatives without external interference (Lewandowska, 2016: 146-147).

The nature of external intervention concerns the definition of what can be considered an 'intervention' or 'restriction'. It is a restrictive act carried out by others that may be deliberate or unintentional (Berlin, 2005: 233-234; Pitsoulis and Groß, 2015: 483). In addition to constraints and barriers, there may be indirect coercion or social pressure that is strong enough to have the same effect as direct coercion (Berlin, 2005; Cherniss, 2013: 30 uses the term 'social control'). 
Restrictions can be interpreted as an opportunity to interfere with an individual's affairs or to force an individual to do something, regardless of the type of power being used (Berlin, 2005; Weinstock, 2009: 848). Kramer (2008) argues in this context that even an unused opportunity to interfere with a subject's affairs may regulate the subject's behaviour by the effort to avoid direct confrontation. In other words, by modifying their behaviour, subjects are limited in terms of negative freedom. When individuals are negatively free, they exist within a space where no such external interference exists. However, if no one is coercing them from the outside because they are doing nothing 'forbidden', they are not negatively free, but they enjoy negative freedom as a state of their existence (i.e. they do not realise that outside inference exists; Cherniss, 2013: 2-3).

Coercion to decide is also an interference (i.e. the 'money or life' dilemma represents coercion and constrains negative freedom). In this case, there is a double coercion. First, the subject is pushed to choose one option because only one option is rationally available (i.e. 'life'). Second, the pressure to choose between only two predetermined possibilities also limits negative freedom (Putterman, 2006: 424).

Another aspect of negative freedom concerns the idea that it is a goal in itself, not the means to achieve something else (Putterman, 2006: 418). People are seen as rational beings who, when making their own choices, will do what is good (at least for themselves). Thus, negative freedom stems from a belief that an individual is able to build his or her life better than other people would have built it for them (Putterman, 2006: 420-421); therefore, it can be held as a universal value.

As a universal value, negative freedom is not limited to being a goal of an individual's pursuit (i.e. as a range of choices of individuals who are not limited by restrictions, interventions, barriers, pressures, and coercion), but it can be a wider societal and political goal. Historically, negative freedom has been linked to the tradition of classical liberalism (Gray, 1980; Lewandowska, 2016). Negative freedom respects the division between the state and society and seeks to reduce the role of the state. People's personal goals and values are understood as the result of their individual choices independent of the social environment. Thus, at the political level, negative freedom focuses on protecting the rights and freedoms of individuals (e.g. movement, speech), which guarantees a space of personal freedom that cannot be violated (Berlin, 2005: 238).

Berlin's concept of negative freedom should, however, be understood within its limits. McBride (1990) argues that Berlin inadequately develops the distinction between negative freedom and social conditions. Understanding freedom as an absence of restriction and barriers is a low-resolution perspective because historical and sociocultural conditions determine range of options subject is capable to conceptualise. The possibility to exercise negative freedom is thus nested in social context that establish the content of subject's choices.

\section{Positive freedom}

Positive freedom represents the idea that everyone is free to act in accordance with what they consider meaningful. Being free means being determined to go one's own way towards one's own understanding of what is the highest value in life (Berlin, 2005: 238-239). Positive freedom is therefore a possibility to move towards some higher value (as 'freedom to', Cherniss, 2013; Lewandowska, 2016: 146). 
Berlin explains this type of freedom with a question: 'What, or who, is the source of control or interference that can determine someone to do, or be, this rather than that?' (Berlin, 2005: 233). Positive freedom is not about the range of options (like negative freedom) but it relates to the determinants of freedom, which are ideals and a sense of meaning (Lewandowska, 2016: 147).

At the individual level, positive freedom means the ability to be a ruler of oneself, based on one's own reasons and ability to set personal goals. It encompasses being reflective of one's own thoughts and actions, responsible for one's own choices, and being able to act on one's own ideals and sense of meaning (Berlin, 2005: 238-239). In this regard, positive freedom presupposes the existence of two selves: higher, rational and moral, and lower, irrational, emotional, and reactive (Berlin, 2005: 240). To achieve positive freedom, it is necessary for the lower self to submit to the higher self. Controlling irrational desires leads to a state of 'real freedom' (positive freedom; Paulíček, 2016: 90).

A very important aspect of achieving individual positive freedom is self-reflection. Self-reflection, as defined by Haworth (1986: 39) in this context of positive freedom, means the ability to reflect critically on one's own goals and personal beliefs and values that would otherwise be passively accepted. Thus, self-reflection is a process of judging beliefs, desires, and meanings. The higher self can control the lower self, and the individual can control what beliefs constitute his or her life. A subject is positively free if he is the active creator of his life and makes decisions by himself (i.e. no one is deciding for him and determining his direction, and he is not acting on the basis of external influences or the wishes of others; a subject is a 'doer'; Berlin, 2005: 238-239; Elford, 2012: 241).

The political notion of positive freedom means conceptualising collective entity as an individual. Society, the church, the community, and the state represent collective entities that are driven by higher goals and that determine which behaviour or state of being is right/good and which is not. Right or good might be extracted from various noble values, such as equality, justice, happiness, culture or security (Berlin, 2005: 239-240). Political and legal systems are built on the assumption that the interests of the collective entity are superior to those of the individual.

Positive freedom assumes that people should live according to a given higher value, and if necessary, they should be taught what this higher value is and how to translate it into practice. To make people positively free, it is necessary to educate/direct them towards the intended concept of morality (Berlin, 2005: 240-241). While negative freedom is a value in itself, positive freedom alludes to some other value or ideal (as a means of achieving it). To achieve this value in practice, it is essential that collective efforts be directed towards obtaining it by public policy interventions (Berlin, 2005: 240; Putterman, 2006: 418).

At the core of the problematic nature of the positive concept of freedom is the belief that every individual has a higher and a lower self and that 'good' individuals are those whose higher self matches the interests of the collective entity (Berlin, 2005: 239-241). A coercive entity personified in the proponents of a collective value assumes that it knows the 'true wishes' of individuals and society (Gustavsson, 2014: 272). It is necessary that the collective entity protects individuals from the threats posed by their lower selves. The aim of such an arrangement is therefore to lead individuals to act according to their 'real' interest and to live the 'right life' (McBride, 1990: 302; Berlin, 2005: 240).

There are however two limits of Berlin conceptualisation of positive freedom that should be taken into account. First, Berlin does not pay sufficient attention to contextual 
Table 1 Types of negative and positive freedom

\begin{tabular}{|c|c|}
\hline Concept & Characteristics \\
\hline Negative Freedom & A space of non-interference \\
\hline $\begin{array}{l}\text { Positive Negative } \\
\text { Freedom }\end{array}$ & Reference value of positive freedom is negative freedom \\
\hline $\begin{array}{l}\text { Monistic Positive } \\
\text { Freedom }\end{array}$ & $\begin{array}{l}\text { There is only one "right" value and/or value order which serves as a } \\
\text { reference value of positive freedom }\end{array}$ \\
\hline $\begin{array}{l}\text { Pluralistic Positive } \\
\text { Freedom }\end{array}$ & $\begin{array}{l}\text { There is a plurality of values and value orders and this plurality is the } \\
\text { reference value of positive freedom }\end{array}$ \\
\hline
\end{tabular}

Source. Author

social conditions. The explanation of positive freedom encoded in the distinction between 'higher' and 'lower' self represents a simplification of complex social processes connected to policy and regulatory institutions (see McBride, 1990). Second, the dynamics of a political arrangement are not in the top-down process of the dominance of a ruling class over individuals. Especially in the context of democratic societies, the vision of a 'good life' is based on shared values mediated via a network of interconnected individuals. Public opinion on what is considered desirable is shaped and communicated within the public discourse. Visions of the 'right life' would be a result of discursive processes and held by collective institutions (Lewandowska, 2016: 147).

Positive freedom is realised when this public discourse is not communicated in the language of imposition but in the language of liberation (hence, positive freedom). Positive freedom is about imposition that is communicated as liberation. The proponents of restrictive policies may not realise that it is an imposition, since the actions they establish are communicated as 'reasonable' and lead to 'increased freedom' (Gustavsson, 2014: 269).

The concept of positive freedom can be distinguished into two types: monism and pluralism. Monism is the belief that there is one absolute universally valid value or value order. Positive freedom is the freedom to choose and act upon that value or value order (Gustavsson, 2014; Lewandowska, 2016: 150). However, according to Berlin, there may be multiple equally relevant, true, and valid values (and value orders) that are incompatible with each other. This concept of incompatible, equally relevant values (including the choice between them) is pluralism. Unlike monism, this view is essentially neutral - there is a plurality of values. Pluralistic positive freedom represents respecting and protecting incompatible value frameworks and orders (O'Neill, 2004: 474; Lewandowska, 2016: 150).

\section{Negative and positive freedom and gender equality}

I have identified three concepts of liberty (monistic positive freedom, pluralistic positive freedom, and negative freedom) that relate differently to the concept of gender equality. In this section, I will summarise this relation, but first I will introduce a new concept of liberty: it is positive negative freedom (for a summary of all notions of freedom see Table 1). 
The concept of positive negative freedom is a concept of positive freedom that takes negative freedom as its reference value. It is positive freedom because it takes into account social context of individuals and attempts to rearrange social conditions of individuals to grant choices to men and women within public/private domain. Simultaneously, it is negative freedom because an aim of such rearrangement is to increase scope of noninterference from subtle forms of coercion arising from embedded gender order. And thus to broaden the negative freedom of all individuals within a society. In the context of gender equality, positive negative freedom responds to classic liberalism. Classic liberalism regarded the organisation of the domestic sphere as unregulatable and private (following the negative notion of freedom, O'Connor et al., 1999). Consequently, it failed to conceptualise women as free individuals with a full range of citizenship rights (Pateman, 1988; O'Connor, 1993). Both of these problems are addressed by the concept of positive negative freedom.

First, negative freedom was formalised as the freedom of non-interference linked primarily to non-interference from larger societal bodies (as classic liberalism was about emancipation from tradition, O'Connor et al., 1999: 47). Berlin was concerned with the question of what constitutes such interference. Framing the answer as existing only within the public sphere thus limited its meaning only to certain forms of barriers, coercion and social control. However, it failed to address the embedded gender order existing in an implied public/domestic distinction. Positive negative freedom extends the space of interference to the domestic sphere. In this way, the requirement for achieving negative freedom encompasses more subtle forms of interference, such as exploitation. Moreover, it provides an imperative for state interference to grant negative freedom to everyone. This was pointed out by Gould's (2013) feminist critique of Berlin, which concluded that the political rights of individuals should be protected to grant freedom of choice to both men and women. This broadening of negative freedom, however, is connected to the state interfering with the labor organisation within families to ensure a space of non-interference for all individuals (thus, positive negative freedom).

Second, negative freedom was historically linked to the public sphere, where its subject was conceptualised primarily as an individual (to whom should be granted liberal rights). Women's theoretical invisibility and their connection to the private sphere made their status as individuals problematic, as their exercise of freedom was rooted in contextual social relations (see Pateman, 1988). The social aspect was, however, fully omitted in doctrines derived from negative freedom, leading to the persistence of the disparities that arose from the gender order. Understanding negative freedom as encompassing all individuals (male and female) makes the case for rearranging society in a manner that allows for choice and grants a space of non-interference to all. This reacts to the necessity of the existence of positive negative freedom as a prerequisite for the existence of negative freedom (because absolute non-interference from the state would be anarchy).

Another concept, negative freedom in the context of gender equality, represents a reduction in state intervention in the reconciliation of family and work. Gender equality may seem to fall under the positive concept of freedom, but as Orloff and Schiff (2015: 7-8) explain, there were already streams within the feminist movement that supported neoliberal politics in the 1980s. For example, these feminists promoted women's employment by eliminating the right to social assistance. Negative freedom can be connected to gender equality as reducing state intervention (tax relief, social assistance, etc.). 
Table 2 Concepts of gender equality

\begin{tabular}{|c|c|c|c|}
\hline $\begin{array}{l}\text { Gender equality } \\
\text { concept }\end{array}$ & Assumption & Principle & Policy example \\
\hline $\begin{array}{l}\text { Inclusion/ } \\
\text { sameness }\end{array}$ & $\begin{array}{l}\text { Women and men are the } \\
\text { same }\end{array}$ & $\begin{array}{l}\text { Inclusion of women } \\
\text { to public sphere }\end{array}$ & $\begin{array}{l}\text { Anti-discrimination/ } \\
\text { removing barriers }\end{array}$ \\
\hline $\begin{array}{l}\text { Reversal/ } \\
\text { difference }\end{array}$ & $\begin{array}{l}\text { Women and men are } \\
\text { different }\end{array}$ & $\begin{array}{l}\text { Compensate for } \\
\text { differences }\end{array}$ & Positive action \\
\hline $\begin{array}{l}\text { Displacement/ } \\
\text { transformation }\end{array}$ & $\begin{array}{l}\text { The existence of gender } \\
\text { norms is the problem }\end{array}$ & $\begin{array}{l}\text { Reconstruct public } \\
\text { discourse }\end{array}$ & $\begin{array}{l}\text { Gender } \\
\text { mainstreaming }\end{array}$ \\
\hline
\end{tabular}

Source. Squires, 1999; Verloo and Lombardo, 2007; adapted by author.

Gender equality in the context of monistic positive freedom means that a specific doctrine (e.g. a certain conceptualisation of gender equality) is taken as the only correct and rational principle upon which society should be organised. However, pluralistic positive freedom aims to protect the plurality of values and different approaches to life. Plurality serves as the highest value towards which the organisation of society should aim. In terms of gender, it is an approach that encourages the creation of a society where everyone can choose their way of life regardless of gender stereotypes or gender order.

\section{The analysis}

The previous section of the article introduced an analytical framework that will be used to examine selected family policy tools that are connected to gender equality. Different concepts of gender equality differ in their strategies for combating inequality, following the traditions of inclusion, reversal, or displacement (Squires, 1999; Verloo and Lombardo, 2007). First, inclusion perceives gender equality as sameness. According to this tradition, incorporating women in public life should be based on understanding people primarily as individuals who have the same rights and opportunities and are judged by the same principles and standards regardless of their gender. Second, reversal understands men and women as inherently different. Following gendered public/private dichotomy it perceives the male gender norm as dominant in public life and female norm as primarily domestic. Thus, policy tools should compensate for differences. Last concept, displacement, aims to transform all norms and standards about what is/should-be associated with male and female identity. This conception challenges all aspects of gender norms by reconstructing the policy discourse.

In this section, the concepts of gender equality will be used as a heuristic to classify identified social policy tools regarding unpaid and paid work. The distinctiveness of three equality concepts is exclusively conceptual, while in practice, policy tools are designed to fulfil specific policy aims from which the three normative approaches are theoretically abstracted (for a summary, see Table 2 - Concepts of Gender Equality).

I have derived the social policy tools that will be analysed from a comprehensive overview created by Stratigaki (2004). She evaluated and compiled a timeline of strategic documents that show the development of the concept of the harmonisation of paid and unpaid work in the EU from 1982 to 2000. The European Union level was selected 
because of the cultural sensitivity of the issue. The tools at the EU level were formulated in a general manner to fit member states with different welfare state regimes. The timeframe covers the formation of the policy agenda of gender equality, the time of its greatest prominence and the beginning of the shift of policy strategies away from ensuring gender equality towards employability, investments, and other economic goals (Jenson, 2008: 146). The period of the 1980s and 1990s thus covers a broad range of policy strategies connected to gender equality concepts while maintaining the policy agenda on gender equality. I have reconstructed the timeline and identified the proposed tools (as shown in Table 3 - Timeline of Work/Family Harmonisation Tools).

The following sections are structured based on the concepts of gender equality. In each section, I will introduce each tool and analyse it based on the four identified concepts of freedom (negative, positive negative, monistic positive and pluralistic positive; the summary can be found in Table 4 - Freedom, Gender Equality and Care-Work Harmonisation Policy Tools).

\section{Inclusion}

Inclusion encompasses policies that address women's integration into the public sphere. The first policy field connected to this concept of equality aims for labour market inclusion by the elimination of discrimination on the labour market, equal pay, and equal treatment at work.

I have identified the elimination of discrimination as a type of positive negative freedom. Although these policies interfere with the behaviour of companies, groups, and individuals, they aim to create a space of non-interference that increases the overall level of negative freedom. Analogous to the establishment of a law, certain actions must be penalised to ensure the broadest possible scope of choices for everyone. The goal of antidiscriminatory policies is the creation of a gender-equal world where both men and women can coexist without interference.

Equal pay, however, is a different type of freedom, as it directly interferes with the way companies operate. In the strict sense of the word, it is not a restriction but a prescription of the way employees should be rewarded. It is therefore a monistic type of positive freedom. It aims to create a gender-equal world where rewarding employees is based not only on an evaluation of results by an employer but also on the political dimension. Equal pay acts as a corrective mechanism of structural inequality between genders. It is not, therefore, an extension of choice but a salary prescription that pursues a single goal: achieving equality.

Equal treatment is a policy that prescribes the conduct of individuals, groups, or institutions to create an environment in which women and men are treated equally and restricts conduct that treats men and women differently. Thus, depending on the nature of the policy, it is a monistic type of freedom, i.e. a prescription of conduct for the purpose of equality, or a positive negative freedom (i.e. a restriction of gender stereotyping that limits oppressive actions based on gender).

The second inclusion policy field includes tools to reconcile work and family. In general, work and family harmonisation tools can fit into multiple gender equality traditions. Therefore, in this section, I will discuss only the instruments that are designed to reconcile work and family and that use gender-neutral language, specifically creating a network of good-quality institutional care for children, promoting flexible and part-time work for all workers and institutionalising parental leave. 
$\vec{o} \quad$ Table 3 Timeline of work/family harmonisation tools

\begin{tabular}{ll}
\hline \hline Year & Name \\
\hline 1982 & $\begin{array}{l}\text { The First Medium-Term Community } \\
\text { Programme on Equal Opportunities } \\
\text { for Women }\end{array}$ \\
1986 & $\begin{array}{l}\text { The Second Medium Term Community } \\
\text { Programme on Equal Opportunities }\end{array}$
\end{tabular}

for Women

1986 The Second Resolution on the Promotion of Equal Opportunities for Women (86/C 203/02)

1990 The Third Community Action Programme on Equal Opportunities for Women and Men

1992 Council Recommendation on Child Care (92/241/EEC)

Author

Commission of the European Communities

Commission of the European Communities

Council of the European

Communities

Commission of the European

Communities

Council of the European

Communities

Description

It extended the scope of existing directives for equal access and equal pay for equal work and focused on equal sharing of parental obligations as a way of improving working condition and living standards (as a prerequisite for equal treatment)

It expressed the need to eliminate discrimination and it promoted sharing family and work responsibilities as a way to achieve equality in the labor market (incl. Creating a social infrastructure to achieve equality).

It aimed for reorganisation of work time patterns.

It stressed the importance of reconciliation of work and family responsibilities for achieving equality. It

highlighted the necessity of childcare provisions and promoted women's employment and training.

It highlighted the importance of sufficient number of good quality childcare facility, incentivise the change of a structure and organisation of work and stressed the role of men in childcare. The
Proposals

Equal Pay

Equal Treatment at

Work

Sharing Work and

Family

Responsibilities

between Partners

Elimination of

Discrimination

Parental Leave

Institutional Childcare

Sharing Work and

Family

Responsibilities between Partners

Flexible Working Arrangements

Reconciliation of Work and Family Institutional Childcare Elimination of

Discrimination

Positive Action (Equal Opportunities) Institutional Childcare 
The White Paper "Growth,

Competitiveness, Employment

1994 The White Paper on European Social Policy

1995 The Fourth Medium Term Community Action Programme on Equal Opportunities for Women and Men 1997 The European Employment Strategy

reconciliation measures addressed both men and women while including positive action measures for women.

European

Commission

European

Commission

Commission of the European

Communities

Treaty of

Amsterdam
The document focused on increasing EU's competitiveness, thus many proposals were linked to economic goals. It, however, initiated a debate on creating flexible working conditions.

It promoted creating new forms of employment for workers who require alternative working hours. It also focused on reconciliation of work and employment by desegregating the labor market and creating equal opportunities for women.

It promoted combining work with family life for both men and women.

The strategy had equal opportunities between women and men as one of the main priorities. It included policies on parental leave, part-time work, childcare provisions to ease women's integration to labor market. It also introduced new tools such as monitoring individual member states or investing via European Structural Fund.
Promotion of Cultural Change

Elimination of

Discrimination

Flexible Working

Arrangements

Flexible Working Arrangements

Positive Action (Equal

Opportunities)

Institutional Childcare

Reconciliation of

Work and Family

Reconciliation of

Work and Family

Institutional Childcare

Parental Leave

Positive Action (Equal

Opportunities)

Flexible Working

Arrangements

Monitoring Member

states for gender

Equality

Reconciliation of

Work and Family 
Table 3. Continued

\begin{tabular}{lllll}
\hline Year & Name & Author & Description & Proposals \\
\hline 2000 & $\begin{array}{l}\text { Conclusions of the Lisbon European } \\
\text { Council }\end{array}$ & $\begin{array}{c}\text { European } \\
\text { Council }\end{array}$ & $\begin{array}{c}\text { This document extended monitoring of national } \\
\text { employment by including indicators that addressed a } \\
\text { number of quality childcare facilities. Furthermore, it } \\
\text { promoted creation of good working environment and } \\
\text { flexible working conditions. }\end{array}$ & $\begin{array}{c}\text { Arrangements } \\
\text { Benchmarking }\end{array}$ \\
& & & $\begin{array}{c}\text { The document focused on gender mainstreaming as a } \\
\text { new way to resolve the issue of gender equality. }\end{array}$ & $\begin{array}{c}\text { Gender } \\
\text { Mainstreaming }\end{array}$ \\
\hline \hline
\end{tabular}

Source. Stratigaki, 2004; adapted by author 
Table 4 Freedom, gender equality and care-work harmonisation policy tools

\begin{tabular}{lll}
\hline \hline $\begin{array}{l}\text { Gender } \\
\text { Equality } \\
\text { Concept }\end{array}$ & Policy Tools & \\
\hline Inclusion & Elimination of Discrimination & Concept of Freedom \\
& Equal Pay & Positive Negative Freedom \\
& Equal Treatment at Work & Monistic Positive Freedom \\
& Positive Negative Freedom/ & Monistic Positive Freedom \\
& Reconciliation of Work and Family (Gender & Positive Negative Freedom \\
& Neutral) & \\
& Flexible Working Arrangements & Positive Negative Freedom \\
& Monitoring for Gender Equality & Monistic Positive Freedom \\
& Sharing Work and Family Responsibilities & Monistic Positive Freedom \\
Reversal & Between Partners & \\
& Institutional Childcare, Parental Leave & Positive Negative Freedom \\
& (Reflecting Gender Differences) & \\
& Positive Action & Positive Negative Freedom/ \\
& & Monistic Positive Freedom \\
& Promotion of Cultural Change & Monistic Positive Freedom \\
& Benchmarking & Unspecified \\
& Gender Mainstreaming & Pluralistic Positive \\
& & Freedom/Monistic Positive \\
& & Freedom
\end{tabular}

Source. Author

These policies are, however, paradoxical. Because they use a gender-neutral language, they nominally pursue the goal of creating a society where men and women will not be pressured into fulfilling the prescribed gender role. Hence, they should be regarded as positive negative freedom. However, in practice, they preserve the gender-conditioned division of unpaid and paid work. Because of their nature, they do not reflect on social pressure to maintain traditional gender roles. This limits the effect of creating a space of non-interference as they do not address cultural pressure directly but merely remove certain obstacles in women's career paths.

Similarly, flexible working arrangements are a gender-neutral policy tool designed to reconcile family and work. I have identified this tool as a positive negative freedom, as it increases the scope of possibilities for employees to choose how to conduct their work time.

Last, monitoring for gender equality aims to create a world in which men and women are equal in terms of the organisation of society (equity). In this respect, it is an instrument supporting the reorganisation of societal activities to achieve the goal of equality of outcomes. It does not take into account any other relevant factors that may play a role in gender organisation or any other type of outcome. For this reason, it is a monistic type of positive freedom. 


\section{Reversal}

Reversal is tied to policies that compensate for gendered differences. The first policy field subsumed under the reversal conception of gender equality is family policies that aim at sharing work and family responsibilities between partners. Specifically, they create highquality institutional childcare, institutionalise parental leave (including paternity leave) and support men's participation in unpaid labour.

The objective of sharing responsibilities aims at the reorganisation of the activities of men and women in the public and private spheres. Equality thus represents a way in which individual families choose the 'right' way of life. It is therefore a monistic type of positive freedom. On the other hand, some measures increase the choices available for both men and women, both nominally and in their implementation, because they reflect structural inequalities between genders and address social pressure based on gender norms (institutional care, parental leave). These represent positive negative freedom.

The second policy field focuses on women's status in the professional environment, i.e. positive action for equal opportunities, which takes gender as the principle of difference. These are equal opportunity policies that compensate women's disadvantages in the labour market. They aim to ease women's entry into the labour market, maximise women's job opportunities, desegregate the market, and help women in the sectors where they are underrepresented. In addition, they address women's training, the reduction of women's risk of unemployment and social exclusion.

I have identified these tools as positive negative freedom, as they aim to increase women's choices for employment by expanding their competencies and to create an environment that is not limited to gender-stereotyped standards. They increase women's range of choice and reduce social pressure; thus, these tools increase the negative freedom of a society as a whole. However, I have excluded tools, such as quotas, that pursue the above objectives in a prescriptive manner. Such policies prescribe specific work organisations and therefore are a monistic type of positive freedom.

The last policy field concerns a promotion of cultural change, such as the elimination of stereotypical attitudes in society, the promotion of sharing household chores and benchmarking based on gender equality. The elimination of stereotypical attitudes in society and the promotion of sharing work and family responsibilities assume a 'right' way of life. These policies thus aim to 'educate' the public to conform to a specific representation of gender equality. They therefore support a monistic type of positive freedom.

Benchmarking is a tool designed to encourage countries to create equal societies. However, more research is necessary to determine the exact type of freedom (monism, pluralism, positive negative) because it depends on the variables measured.

\section{Displacement}

Policy tools that stem from the concept of displacement aim to reconstruct public discourse and transform existing gender norms. Gender mainstreaming is the only policy measure connected to the displacement conception of gender equality. It can be classified into two types of positive freedom. When conceptualising gender mainstreaming as a policy aim, it is a pluralistic type of positive freedom. This tool seeks to create a society in which every individual (regardless of gender) can choose the way she/he wants to live life (without complying with gender norms). Gender mainstreaming is not prescriptive in the 
way one 'should' live; rather, it seeks to create a system in which every individual can choose his or her way of life.

However, when conceptualising gender mainstreaming as policy practice, I argue that it is a monistic type of positive freedom. Gender mainstreaming means assessing the implications of a specific policy on men's and women's interests and concerns. In its implementation, gender mainstreaming usually means raising an issue of gender identity in sectors that are primarily concerned with other activities. Thus, restructuring the discourse means in practice prescribing a way in which policy institutions should act to achieve equality.

\section{Conclusion}

The gender equality discussion in social policy was based on a specific notion of freedom connected to social liberalism. Existing theoretical arguments connected to gender equality and freedom were derived from the dichotomy between the masculine/public and feminine/private/domestic spheres. This gendered dichotomy translated into the conceptualisations of freedom, whether considering only individuals and their own choices (negative freedom) or understanding subjects as contextually social in their capability to make choices (positive freedom). This article reflected on these underpinnings by transcending established dichotomies of positive/negative freedom and public/private.

The nature of any social contract endows a popular sovereign with power over its subjects, giving legitimacy to state intervention and governance over people. The nature of such interventions is not, even in classic liberal doctrine, divorced from the private sphere. This means that restrictions imposed on individuals to protect freedom of movement, speech or property are justifiable if they lead to broadening the overall space of non-interference (negative freedom). Positive negative freedom is necessary for negative freedom to exist. What proved problematic from the feminist perspective, however, is the historical continuity of an implicit gender order embedded in the public-private dichotomy. The successor of classic liberalism, neo-liberalism, still maintains this gendered public/private distinction. It has failed to address the familial assumptions of classic liberalism despite its claims of genderless individualism (O'Connor et al., 1999). Taking the perspective of positive negative freedom, this article attempted to divorce from these historical contingencies. Positive negative freedom understands all individuals, male and female, to be granted a space of non-interference, as it addresses the conditions under which such a space can arise. Thus, positive negative freedom fits gender equality into liberal thought by blurring the historically established line between the public and domestic spheres.

Going beyond the binary distinction between positive and negative freedom, there are four main conclusions that can be drawn from this article. First, the article suggested a complex relationship between freedom and equality. Gender equality shares with positive freedom its reflection on social conditions of individuals, reflecting particularly on gender order embedded within social institutions and social structure. Simultaneously, gender equality can be translated into policy tools that expand the scope of choices for both men and women concerning the organisation of domestic matters and that grant women choices in their activities within public sphere. Gender equality and freedom thus share various traits that can be identified in proposed policies. In this analysis many work-family 
reconciliation tools were identified as positive negative freedom which suggests there might be an influence of other principles connected to both, gender equality and freedom (i.e. equality of opportunity). These relations are not yet elaborated in social policy theorising.

Second, the analysis showed that the specific notion of gender equality (i.e. the specific representation of what gender equality means) does not have direct implications for individual's freedom as it is mediated via selected policy tool. The precise impact on individual's freedom stems from formulation, aim and form of implementation of a specific policy tool. This suggests that reconciliation and boundaries between freedom and gender equality are not purely a theoretical problem, but also an issue of policy formulation and bureaucratic processes (see Carlsson, 2020). Formulation of policy aims, tools and their implementation suggest that freedom and equality are closely tied to conditions that produced given policy. The contemporary policy debates connecting health crises and financial challenges in the post-COVID world opened a window of opportunity for more progressive, equal and inclusive policies (Ihlamur-Öner, 2020). This article offers a framework that can contribute to these debates by reflecting on impact new policies might have on freedom and equality.

Third, negative freedom is understood as a space of non-interference, historically connected to public sphere. The article, however, broadens the notion of interference to social control derived from embedded gender order and focused on policies which intervene within families. From this perspective, gendered division of labour suggests a limited possibility for women to be free individuals. Work-family reconciliation policies analysed in this article are transcending the public-private dichotomy, while simultaneously many of these tools were identified as positive negative freedom. This suggests that specific family policy tools and policy intervention within families is prerequisite of a liberal society. The effects of social policies on individuals' freedom can be assessed and discussed based on the presented conceptual perspective.

Fourth, this article also hinted at the boundaries of gender equality within the liberal tradition. Policies assigned to monistic positive freedom have inherent totalitarian and authoritarian tendencies because they are closely tied to a specific value or value order (see Brochard et al., 2020). Such policies are prescriptive in instituting the 'right' way of life citizens should follow. Thus, gender equality policies can not only free women and men from the shackles of gendered social order but also contain an inherent danger for freedom. To avoid simplification, this danger can manifest seriously only if the inherent value order and its institution take over the policy agenda. What is, however, immediately relevant about this tendency is the fact that monistic positive freedom represents a limit within the liberal tradition. In other words, the more restructuring a society undergoes to achieve a singular value or value order, the less liberal the society becomes.

This article thus showed that social liberalism can exist in many different variants based on the specific nature and implementation of the proposed social policies. This finding opens up many new themes worth investigating. First, within social liberalism and gender equality, the impact of specific social policy strategies and tools on people's freedom should be assessed. Second, the article opened a question of what level of state intervention in the private sphere is justifiable when taking into account all four concepts of liberty and specifically, where one can redraw the line between the public and private spheres. Finally, the specific and subtle boundaries between all three notions of positive freedom in various policy contexts remain open to discussion. 


\section{References}

Berlin, I. (2005) 'Two concepts of liberty', in N. Warburton (ed.), Philosophy the Basic Readings, $2^{\text {nd }}$ edn, London, UK: Routledge, 232-42.

Brochard, D., Charpenel, M. and Pochic, S. (2020) 'Pay equity through collective bargaining: when voluntary state feminism meets selective business practice', French Politics, 18, 1-2, 93-110.

Carlsson, V. (2020) 'Governance structure and ideology: analysing national administrative conditions for gender equality in the EU's regional policy', NORA - Nordic Journal of Feminist and Gender Research, 28, 2, 153-66.

Cherniss, J. L. (2013) A Mind and its Time, Oxford, UK: Oxford University Press.

Elford, G. (2012) 'Reclaiming two concepts of liberty', Politics, Philosophy and Economics, 12, 3, 228-46.

Gornick, J. C. and Meyers, M. K. (2002) Building the Dual Earner/Dual Career Society: Policy Developments in Europe, CES Working Paper, no. 82, Cambridge: Center for European Studies Harvard.

Gould, C. C. (2013) 'Retrieving positive freedom and why it matters', in B. Baum and R. Nichols (eds.), Isaiah Berlin and the Politics of Freedom, New York, NY: Routledge, 102-13.

Gray, J. N. (1980) 'On negative and positive liberty', Political Studies, 28, 4, 507-26.

Gustavsson, G. (2014) 'The psychological dangers of positive liberty: reconstructing a neglected undercurrent in Isaiah Berlin's "Two Concepts of Liberty"', The Review of Politics, 76, 2, 267-91.

Haworth, L. (1986) Autonomy: An Essay in Philosophical Psychology and Ethics, New Haven, CT: Yale University Press.

Ihlamur-Öner, S. G. (2020) 'Towards a progressive agenda for the EU?', Marmara Journal Of European Studies, 28, 1, 123-46.

Jenson, J. (2008) 'Writing women out, folding gender in: the European union "modernises" social policy', Social Politics: International Studies in Gender, State and Society, 15, 2, 131-53.

Knijn, T. and Kremer, M. (1997) 'Gender and the caring dimension of welfare states: toward inclusive citizenship', Social Politics: International Studies in Gender, State and Society, 4, 3, 328-61.

Korpi, W. (2000) 'Faces of inequality: gender, class, and patterns of inequalities in different types of welfare states', Social Politics: International Studies in Gender, State and Society, 7, 2, 127-91.

Kramer, M. H. (2008) 'Liberty and domination', in C. Laborde and J. Maynor (eds.), Republicanism and Political Theory, Oxford, UK: Blackwell Publishing, 31-57.

Lewandowska, K. (2016) 'Using Isaiah Berlin's two concepts of liberty to rethink cultural policy: a case of Poland', International Journal of Cultural Policy, 24, 2, 145-63.

Lewis, J. (1997) 'Gender and welfare regimes: further thoughts', Social Politics: International Studies in Gender, State and Society, 4, 2, 160-77.

Lewis, J. (2006a) 'Employment and care: the policy problem, gender equality and the issue of choice', Journal of Comparative Policy Analysis: Research and Practice, 8, 2, 103-14.

Lewis, J. (2006b) 'Work/family reconciliation, equal opportunities and social policies: the interpretation of policy trajectories at the EU level and the meaning of gender equality', Journal of European Public Policy, 13, 3, 420-37.

McBride, W. L. (1990) "Two concepts of liberty" thirty years later: a Sartre-inspired critique', Social Theory and Practice, 16, 3, 297-322.

O'Connor, J. S. (1993) 'Gender, class and citizenship in the comparative analysis of welfare state regimes: theoretical and methodological issues', The British Journal of Sociology, 44, 3, 501-18.

O'Connor, J. S., Orloff, A. S. and Shaver, S. (1999) 'Liberalism, gender and social policy', in J. S. O'Connor, A. S. Orloff and S. Shaver (eds.), States, Markets, Families: Gender, Liberalism and Social Policy in Australia, Canada, Great Britain and the United States, Cambridge, UK: Cambridge University Press, 43-65.

O'Neill, T. P. (2004) 'Two concepts of liberty valance: John Ford, Isaiah Berlin, and tragic choice on the frontier', Creighton Law Review, 37, 471-92.

Orloff, A. (1996) 'Gender in the welfare state', Annual Review of Sociology, 22, 1, 51-78. 
Orloff, A. and Schiff, T. (2015) 'Feminists in power: rethinking gender equality after the second wave', in R. Kosslyn and R. Scott (eds.), Emerging Trends in the Social and Behavioral Sciences, Hoboken, NJ: Wiley, $1-15$.

Orloff, A. S. (1992) 'Gender and the social rights of citizenship: the comparative analysis of gender relations and welfare states', American Sociological Review, 58, 3, 303-28.

Pateman, C. (1988) The Sexual Contract, Stanford, CA: Stanford University Press.

Pateman, C. (2004) 'Democratizing citizenship: some advantages of a basic income', Politics and Society, $32,1,89-105$.

Paulíček, I. (2016) 'Sloboda v ponímaní Isaiaha Berlina', Studia Philosophica, 63, 1, 85-94.

Pfau-Effinger, B. (2005) 'Welfare state policies and the development of care arrangements', European Societies, 7, 2, 321-47.

Pitsoulis, A. and Groß, S. W. (2015) "The other side of the argument": Isaiah Berlin versus F. A. von Hayek on liberty, public policies, and the market', Constitutional Political Economy, 26, 4, 475-94.

Putterman, T. L. (2006) 'Berlin's two concepts of liberty: a reassessment and revision', Polity, 38, 3, 416-46.

Ray, R., Gornick, J. C. and Schmitt, J. (2010) 'Who cares? Assessing generosity and gender equality in parental leave policy designs in 21 countries', Journal of European Social Policy, 20, 3, 196-216.

Sainsbury, D. (1996) Gender Equality and Welfare States, Cambridge, UK: Cambridge University Press.

Sainsbury, D. (1999) 'Gender, policy regimes, and politics', in D. Sainsbury (ed.), Gender and Welfare State Regimes, Oxford, UK: Oxford University Press, 245-76.

Squires, J. (1999) Gender in Political Theory, Cambridge, MA: Polity Press.

Stratigaki, M. (2004) 'The cooptation of gender concepts in EU policies: the case of "reconciliation of work and family"', Social Politics: International Studies in Gender, State and Society, 11, 1, 30-56.

Verloo, M. and Lombardo, E. (2007) 'Contested gender equality and policy variety in Europe introducing a critical frame analysis approach', in M. Verloo (ed.), Multiple Meanings of Gender Equality, New York, NY: Central European University Press, 21-50.

Weinstock, D. M. (2009) 'Berlin's metholodological parsimony', San Diego Law Review, 46, 839-58. 